\title{
Analysis of Logistics Delivery Performance (A Case Study of Rental ToolsDelivery in "XYZ" Power Plant Project at The Energy Service Fossil Division) RINALDI RAYMOND ${ }^{1}$, NILA K. HIDAYAT ${ }^{2}$, LINUS PASASA ${ }^{3}$, EFRATA D. S. YUNUS ${ }^{4}$ \\ ${ }^{1}$ Swiss German University, Tangerang Selatan, Indonesia \\ ${ }^{2}$ Padjadjaran University, Bandung, Indonesia \\ ${ }^{3}$ Swiss German University, Tangeang Selatan, Indonesia \\ ${ }^{4}$ Padjadjaran University, Bandung, Indonesia \\ Email Corespondence: rinaldi_rymnd@yahoo.com,nila.hidayat@gmail.com, linus.pasasa@sgu.ac.id, efratadenny@gmail.com
}

\section{Abstract}

The purpose of this study is to analyze the logistics delivery performance of rental tools delivery for temporary import in XYZ Power Plant Project at the Energy Service Division. This research is a mixture of quantitative and qualitative research and using both primary and secondary data, which collected from the company data including interview with the logistics manager and monitoring delivery data of XYZ Power Plant Project in the Logistics Department Energy Service Division. After the data was gathered, AMOS software is used to provide Structural Equation Modeling (SEM) and Path Diagram in order to identify influential factors to logistics delivery performance. Furthermore, to measure the $\mathrm{KPI}$ in terms of delivery reliability of logistics delivery performance levels of rental tools in XYZ power plant project in 2013 by the logistics department in the energy service fossil division. This study uses time series data from September 2013 - December 2013. Based on the results of research, it can be seen that customs clearance has positive moderate correlation to the logistics delivery performance, while number of items factor has a positive weak correlation to the logistics delivery performance. This research also found that the KPI in terms of delivery reliability of delivery performance level of rental tools in XYZ power plant project 2013 by the logistics department in the energy service division is 56.67\%" which is Insufficient in logistics benchmark level. Thus, in purpose of increasing the logistics delivery performance in the XYZ Power Plant Project, the company should improve the delivery reliability. In addition the company should pay more attention to customs clearance process, since customs clearance is the most influential factor to the logistics delivery performance.

Keywords: Logistics, Delivery Reliability, KPI, Temporary Import, On-Time Delivery.

\section{Analisis Logistik Kinerja Pengiriman (Studi Kasus Rental Alat Pengiriman "XYZ" Proyek Daya Pembangkit Listrik di Divisi Layanan Energi Fosil)}

\begin{abstract}
Abstrak
Tujuan dari penelitian ini adalah untuk menganalisis kinerja pengiriman logistik alat rental pengiriman untuk impor sementara di XYZ Proyek Daya Pembangkit Listrik di Divisi Layanan Energi Fosil. Penelitian ini merupakan campuran penelitian kuantitatif dan kualitatif dan menggunakan kedua data primer dan sekunder, yang dikumpulkan dari data perusahaan termasuk wawancara dengan manajer logistik dan pemantauan pengiriman data dari Proyek XYZ Daya Pembangkit Listrik di Divisi Layanan Energi Fosil Setelah data dikumpulkan, software AMOS digunakan untuk menyediakan Structural Equation Modeling (SEM) dan Path Diagram untuk mengidentifikasi faktor-faktor yang berpengaruh terhadap kinerja pengiriman logistik. Selanjutnya, untuk mengukur KPI dalam hal keandalan pengiriman tingkat kinerja pengiriman logistik dari alat sewa di XYZ proyek pembangkit listrik pada 2013 oleh departemen logistik di divisi fosil layanan energi. Penelitian ini menggunakan data time series dari September 2013 - Desember 2013. Berdasarkan hasil penelitian, dapat dilihat bahwa bea cukai memiliki korelasi moderat positif terhadap kinerja pengiriman logistik, sementara jumlah faktor item memiliki korelasi yang lemah positif untuk logistik kinerja pengiriman. Penelitian ini juga menemukan bahwa KPI dalam hal keandalan pengiriman tingkat kinerja pengiriman alat sewa di XYZ proyek pembangkit listrik 2013 oleh departemen logistik di divisi layanan energi 56,67\% "yang tidak mencukupi di tingkat logistik patokan. Dengan demikian, dalam tujuan meningkatkan kinerja pengiriman logistik di Proyek XYZ daya pembangkit, perusahaan harus meningkatkan keandalan pengiriman. Selain itu perusahaan harus lebih memperhatikan proses bea cukai, karena bea cukai adalah faktor yang paling berpengaruh terhadap kinerja pengiriman logistik.
\end{abstract}

Kata Kunci: Logistik, keandalan pengiriman, KPI, Impor Temporer, Pengiriman tepat waktu 


\section{INTRODUCTION}

Logistics has an important part in a company as assisting the company's core business. Therefore it requires effective delivery process to achieve delivery target. If the goods or raw material were late, and as a result delay in the execution of the project it may cause penalties in certain projects. According to Baritz \& Zissman (1983) there are several common customer service complaints. The previous research in Figure 1.1 shows what the respondents felt were the most common service failures. Late delivery, a logistics customer service variable, accounted for nearly half of the mentioned service infractions while product quality mistakes represented about a third.

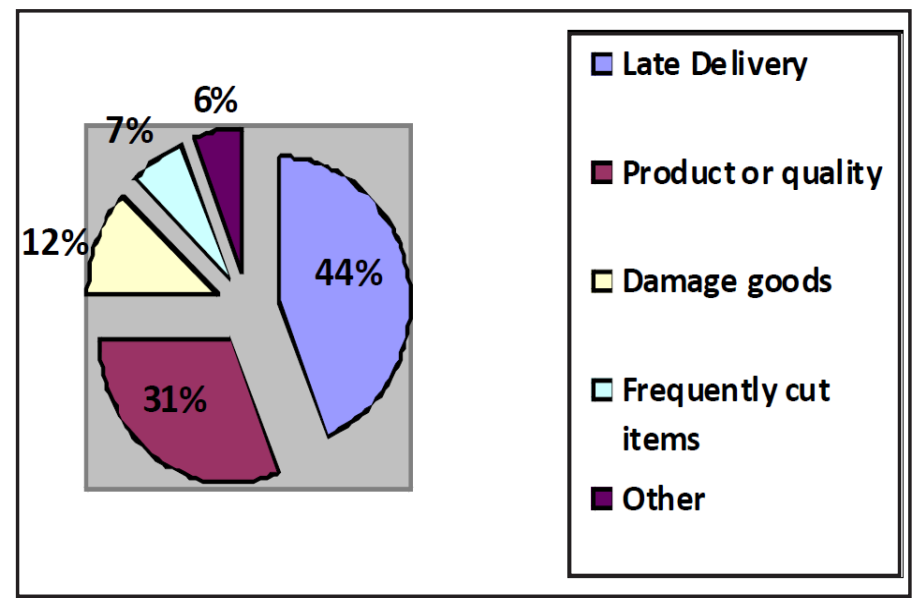

Source: Baritz and Zissman. (1983)

Figure 1.1 Common Customer Service Complaints

Moreover, one of the most obvious features is delivery performance. This aspect generally has two dimensions: speed and reliability (Stock et al., 1998). Speed is meant in the sense of having short lead, response and delivery times as well as the being flexibility to be able to quickly adjust the organisation and respond to new demands while reliability refers to the number of items delivered on time divided by total number of deliveries. Moving products across international borders is like negotiating an intricate maze, riddled with potential pitfalls. Global logistics, though global in nature, must still take into account national and regional differences (Russel \& Taylor 2011). Customs, business practices, and regulations can change widely from country to country and even domestically within a country.

Currently logistics encompasses an array of essential activities for trade-including transport, customs clearance, distribution, and payment systems.

Today logistics is an essential part of a company, due to transporting and arranging the goods or raw materials which have to be met the delivery achievement target. (Ballou, 1998). In addition, it also handles the exportimport process and communicates with the supplier and the customer. If the delivery process in logistics is not effective it will delay the execution of the project and when this happens it may result in penalty for certain projects. Jonsson \& Mattsson (2005) stated it is impossible to attain efficient logistics system, if it is not time efficient.

On the other hand, identifying the several factors that can influence late deliveries is important to achieve delivery achievement target and to avoid penalty in certain projects which could negative impact to the company's revenue. XYZ Company in the energy service division has a power plant project. The problem is there were late deliveries of rental tools in XYZ power plant project in 2011.

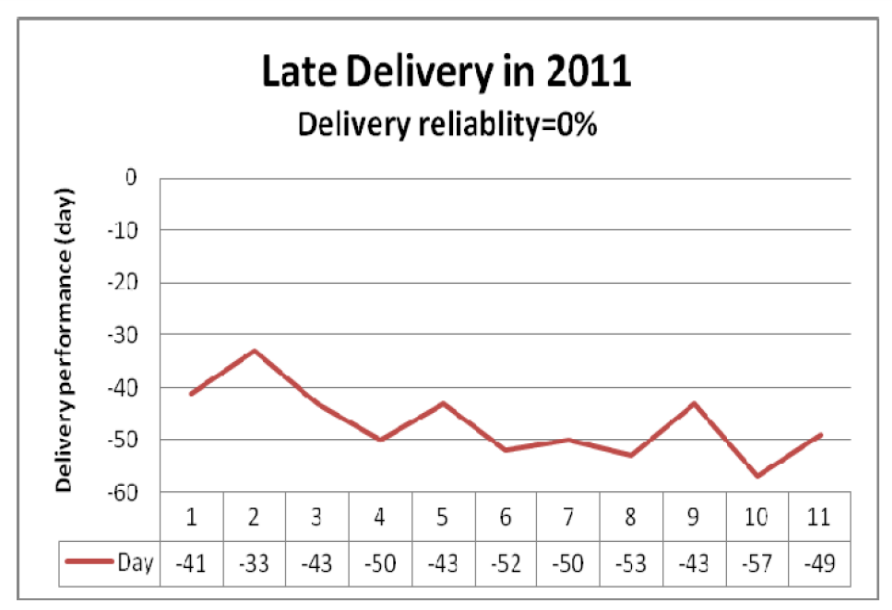

Source: Company data (2013)

Figure 1.2 Late Delivery in XYZ Power Plant Project 2011

According to Figure 1.2 late delivery in $\mathrm{XYZ}$ power plant project was the main issue in 2011 with delivery reliability $0 \%$, which had a direct impact on achieving total target time of the project. Furthermore logistics department is supporting department to the project. Along with the vision of the energy service division is to be the first choice service supplier of spare parts as well as rental tools for power generation assets worldwide. The goal is to eliminate the delays 
that waste time. The focus is on measuring and achieving on-time delivery. There are numerous KPIs to measure logistics performance. However, just-in time shipping requirements and delayed customs or security clearance make on-time delivery KPI number one $(\mathrm{GCl}, 2013)$. Therefore it requires an efficient logistics delivery process by appointing number of key performance indicators that are relevant to the specific problem.

\section{METHOD}

There are 3 questions that will be answered through this research: (1) How does the delivery process flow of temporary import (rental tools) by the logistics department in the energy service division work?. (2) What is the KPI in terms of delivery reliability of logistics delivery performance level of rental tools in XYZ power plant project in 2013 by the logistics department in the energy service division?. (3) What are the influential factors to logistics delivery performance in XYZ power plant 2013 by logistics department in the energy service division?.

This research answer each question in an orderly way to reach the conclusion. To answer those questions, there are some methodologies that were used. (See Table 1).

Table 1 Summary of Methodologies

\begin{tabular}{|c|c|c|}
\hline Questions & Methodologies & Details \\
\hline \multirow{2}{*}{ Number 1} & In-depth Interview & $\begin{array}{l}\text { Interviewees: Logistics Manager (Energy } \\
\text { Service Division }\end{array}$ \\
\hline & Inductive Theory & Experience from the organization \\
\hline \multirow[t]{2}{*}{ Number 2} & Company Data & $\begin{array}{l}\text { Monitoring List Data } 2013 \text { (Source: } \\
\text { Company) }\end{array}$ \\
\hline & Analysis by SPSS & Calculating the Delivery Reliability \\
\hline \multirow[t]{4}{*}{ Number 2} & Deductive Theory & $\begin{array}{l}\text { Previous Research: Delivery Reliability } \\
\text { (Number of Delivery on Time / Total } \\
\text { Number of Deliveries) }\end{array}$ \\
\hline & Inductive Theory & Experience from the organization \\
\hline & Deductive Theory & Previous Research \\
\hline & Company Data & $\begin{array}{l}\text { Monitoring List Data } 2013 \text { (Source: } \\
\text { Company) }\end{array}$ \\
\hline Number 3 & Research Model & $\begin{array}{l}\text { Independent Variables: Trade Ministry } \\
\text { Permit Submission, Trade Ministry } \\
\text { Issuance, Customs Permit Submission, } \\
\text { Customs Permit Issuance, Bank } \\
\text { Guarantee, PIB Issuance, PIB Payment, } \\
\text { SPPB (Customs Release), Number of } \\
\text { Items, Incoterms, Documents }\end{array}$ \\
\hline
\end{tabular}

Continue Tabel 1 Summay of Methodologies

\begin{tabular}{lll}
\hline Questions & Methodologies & \multicolumn{1}{c}{ Details } \\
\hline & & $\begin{array}{l}\text { Dependent Variables: Logistics Delivery } \\
\text { Performance } \\
\text { Rumber 3 }\end{array}$ \\
& Analysis by AMOS & $\begin{array}{l}\text { Pediating Variables: Permit and } \\
\text { Customs Clearance }\end{array}$ \\
& Analysis by SPSS & Calculating Correlation Coefficient \\
\hline
\end{tabular}

\section{RESULT AND DISCUSSION}

\section{Findings}

There are several that answer the research questions.

\section{Finding 1: Delivery Process Flow}

The in-depth interview with the logistics manager was conducted to describe the standard operating procedure for temporary import (rental tools). According to the interview there is a current standard operating procedure of temporary import (rental tools) delivery process flow by the logistics department in the energy service division in Figure 1 below.

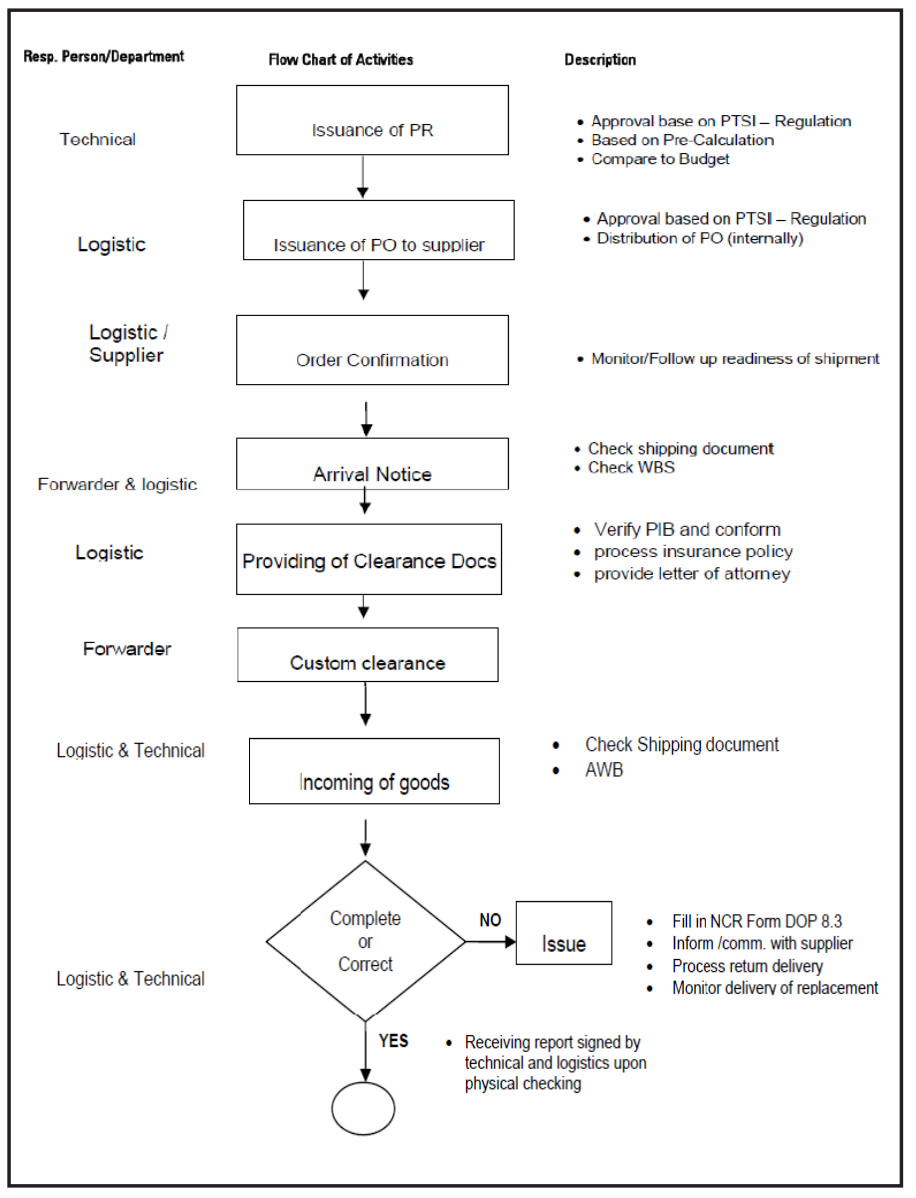

Figure 1 Current Standard Operating Procedure for Temporary Import (Rental Tools) 


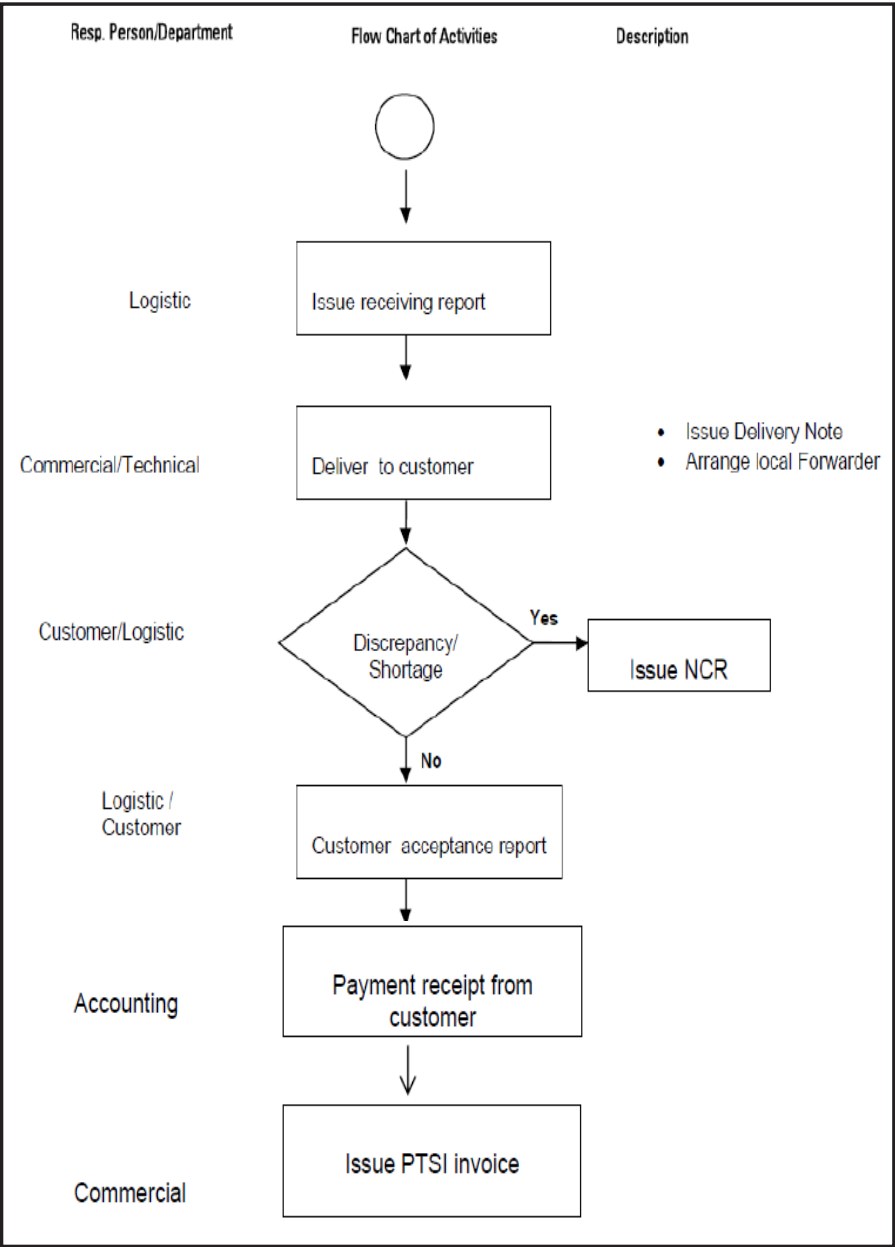

Continue Figure 1 Current Standard Operating Procedure for Temporary Import (Rental Tools)

Based on Figure 1 the current standard operating procedure describe the temporary import (rental tools) flow in general delivery process. However the current standard operating procedure is not detail and focus on temporary import (rental tools) activity. Therefore the researcher made an improvement to propose the new standard operating procedure. There are some processes in sequence and detail which focus on temporary import activity for rental tools in the propose standard operating procedure (please see the appendix 1).

Findings 2: The KPI in terms of delivery reliability of logistics delivery performance levels for rental tools in $\mathrm{XYZ}$ power plant project in 2013

The KPI in terms of delivery reliability was used to measure the second research question. According to Christopher (2005) delivery reliability has gained increased importance as many companies have decreased the inventory levels and increased the number of transports. Therefore delivery reliability is appropriate to this case study because in this project company has not inventory to keep the goods on temporary storage, since in this case study is a trading business, so does not need an inventory. Furthermore According to Jonsson \& Mattsson (2005) the KPI in terms of delivery reliability can be measured through delivery reliability. Below the formula for calculating the delivery reliability in this thesis is given.

$$
\text { Delivery Reliability }=\frac{\text { Number of Delivery on Time }}{\text { Total Number of Deliveries }}
$$

Moreover the Table 2 shows delivery performance benchmark logistics department at PTSI and its classification of logistics delivery performance levels.

Table 2 Logistics Delivery Performance Benchmark

\begin{tabular}{clc}
\hline No & Performance Class & Range for Delivery Performance \\
\hline 1 & Outstanding & $90 \%-100 \%$ \\
2 & Good & $70 \%-89 \%$ \\
3 & Insufficient & $50 \%-69 \%$ \\
4 & Poor & $<50 \%$ \\
\hline
\end{tabular}

Source: Company Data (2013)

After analyzed which based on the monitoring list (company data), there are 30 in total number of deliveries while the total number of delivery on time were 17. According to Jonsson \& Mattsson (2005) the $\mathrm{KPI}$ in terms of delivery reliability can be measured by calculating the number of deliveries on time divided by total number of deliveries. Based on the calculating of delivery reliability from the monitoring list (company data). Furthermore, comparing the actual date of delivery to the one confirmed by the company to the customer (target date). Therefore the result for delivery reliability calculation is shown in Figure 2.

The result for delivery reliability calculation is $56.67 \%$. Since $56.67 \%$ is in the range Insufficient. Thus, The KPI in terms of delivery reliability of delivery performance level of rental tools in XYZ power plant project 2013 by the logistics department in the energy service division is Insufficient. 
ISSN 1412 - 3681

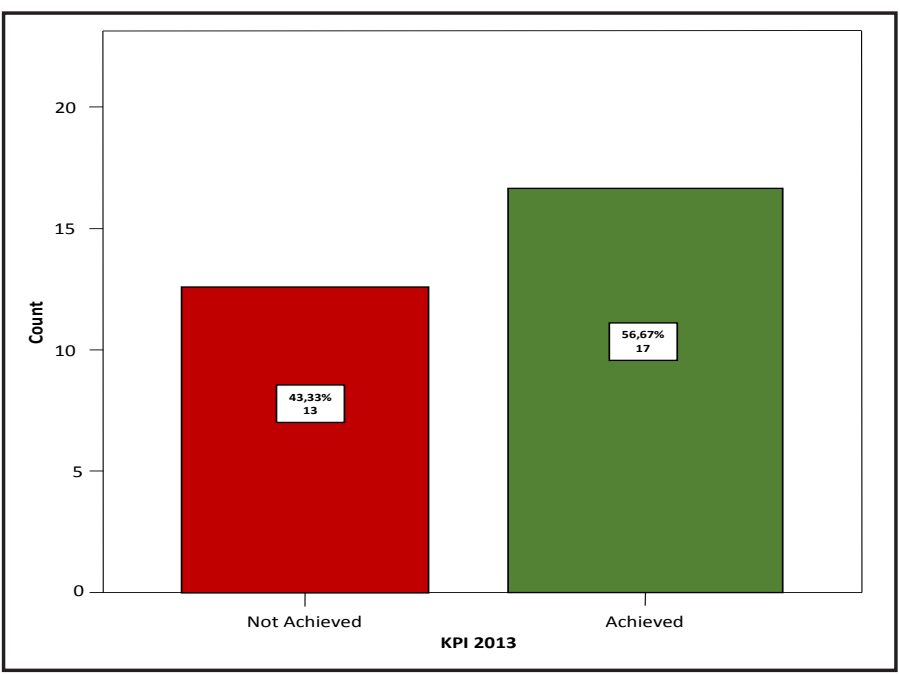

Source: Data on File (2013)

Figure 2 Delivery Reliability Result in XYZ Power Plant Project in 2013

Findings 3: The influence factors to logistics delivery performance in XYZ power plant project in 2013

SEM was used to estimating causal relationship using a combination of statistical data and qualitative causal assumptions (Hair et.al 2006). Typically, this theory represents "causal" processes that produce examinations on multiple variables. SEM incorporates observed variables and unobserved variables into the analyses. Unobserved variables called latent variable or mediating variable is the factor that is measured by the indicators (observed variables or manifest variables) gathered through various data collection method.

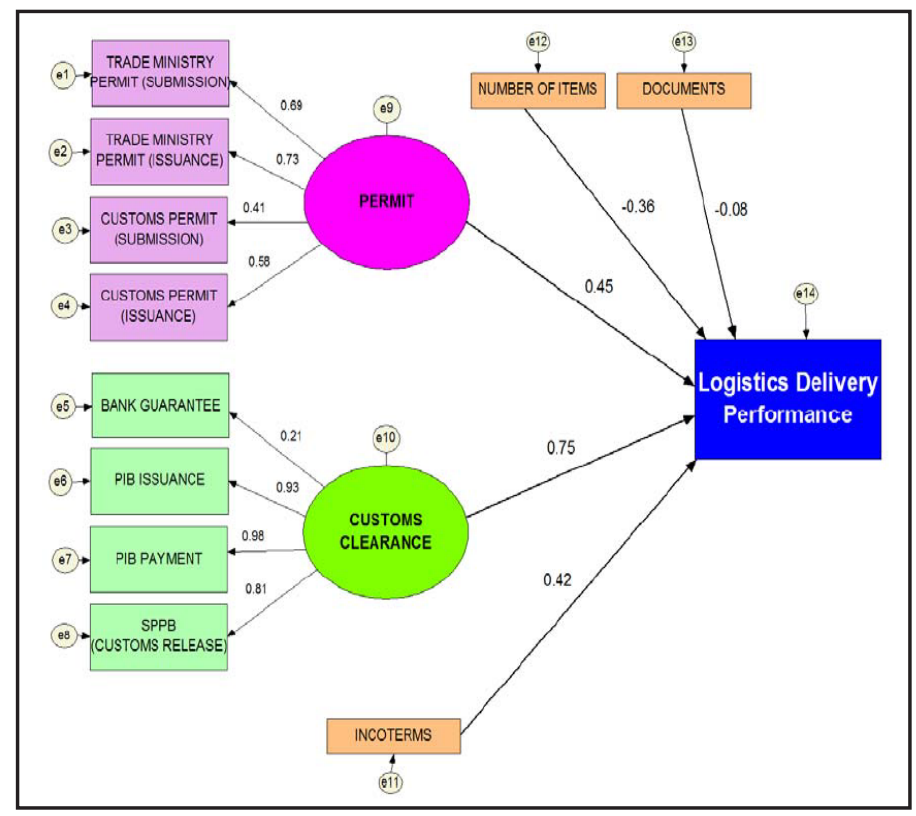

Figure 3 Path Coefficient of Logistics Delivery Performance
Table 3

Path Diagram Interpretation of Logistics Delivery Performance

\begin{tabular}{clccc}
\hline No & \multicolumn{1}{c}{ Factor } & $\begin{array}{c}\text { Coefficient } \\
\text { Correlation } \mathrm{r}\end{array}$ & $\begin{array}{c}\text { Square } \\
\text { Correlation } \mathrm{R}^{2}\end{array}$ & $\begin{array}{c}\text { Strength of } \\
\text { Association }\end{array}$ \\
\hline 1 & Number of Items & -0.36 & $12.96 \%$ & Very weak \\
2 & Documents & -0.08 & $0.64 \%$ & None \\
$3 \quad$ Permit & 0.45 & $20.25 \%$ & Weak \\
4 & Customs Clearance & 0.75 & $56.25 \%$ & Moderate \\
5 & Incoterms & 0.42 & $17.46 \%$ & Weak \\
\hline Source: Data on File (2013) & &
\end{tabular}

The first interpretation is on the Logistics Delivery Performance model. From the analysis using AMOS software version 21 and from the summary results in Table 3 we can find that there are positive relationships between Permit, Customs Clearance, and Incoterms factors in influencing logistics delivery performance in a power plant 2013 by logistics department in the energy service division. On the contrary, Number of Items and Documents factors are negative relationships to logistics delivery performance. The strongest influenced to logistics delivery performance is Customs Clearance has a positive correlation and also the highest correlation with $r=0.75, R^{2}=56.25 \%$ and strength association "moderate". It has a big influence to logistics delivery performance.

Table 4

Path Diagram Interpretation of Permit Model

\begin{tabular}{clccc}
\hline No & \multicolumn{1}{c}{ Factor } & $\begin{array}{c}\text { Coefficient } \\
\text { Correlation r }\end{array}$ & $\begin{array}{c}\text { Square } \\
\text { Correlation } \mathbf{R}^{2}\end{array}$ & $\begin{array}{c}\text { Strength of } \\
\text { Association }\end{array}$ \\
\hline 1 & $\begin{array}{l}\text { Trade Ministry } \\
\text { Permit (Submission) }\end{array}$ & 0.69 & $47.61 \%$ & Moderate \\
$2 \quad \begin{array}{l}\text { Trade Ministry } \\
\text { Permit (Issuance) }\end{array}$ & 0.73 & $53.29 \%$ & Moderate \\
3 & $\begin{array}{l}\text { Customs Permit } \\
\text { (Submission) }\end{array}$ & 0.41 & $16.81 \%$ & Weak \\
4 & $\begin{array}{l}\text { Customs Permit } \\
\text { (Issuance) }\end{array}$ & 0.58 & $33.64 \%$ & Weak \\
\hline
\end{tabular}

The second interpretation is on the Permit model (see Table 4). The four factors that influence the Permit variable are Trade Ministry Permit (Submission), Trade Ministry Permit (Issuance), Customs Permit (Submission), and Customs Permit (Issuance). 
Table 5 Path Diagram Interpretation of Customs Clearance Model

\begin{tabular}{ccccc}
\hline No & Factor & $\begin{array}{c}\text { Coefficient } \\
\text { Correlation } \mathbf{r}\end{array}$ & $\begin{array}{c}\text { Square } \\
\text { Correlation } \mathbf{R}^{2}\end{array}$ & $\begin{array}{c}\text { Strength of } \\
\text { Association }\end{array}$ \\
\hline 1 & Bank Guarantee & 0.21 & $4.41 \%$ & Very weak \\
2 & PIB Issuance & 0.93 & $86.49 \%$ & Strong \\
3 & PIB Payment & 0.98 & $96.04 \%$ & Strong \\
4 & SPPB (Customs Release) & 0.81 & $65.61 \%$ & Strong \\
\hline
\end{tabular}

The next interpretation is on the Customs Clearance Factor model (see Table 5. The four factors that influence the Customs Clearance Factor are Bank Guarantee, PIB Issuance, PIB Payment, and SPPB (Customs Release). From Table 5, it is shown that the factor PIB Payment has the highest correlation with $r$ $=0.98, R^{2}=96.04 \%$ and strength association "strong". Second most influence on Customs Clearance is factor PIB Issuance with coefficient correlation 0.93 $\left(R^{2}=86.49 \%\right)$. Third most influence on Customs Clearance is SPPB (Customs Release) with $0.81\left(R^{2}=\right.$ $65.61 \%)$. Lastly, Bank Guarantee factor is in the lowest correlation to Customs Clearance ( $\left.r=0.21, R^{2}=4.41 \%\right)$. and strength association "very weak".

The current late delivery process is caused by PIB Payment from company. It depends on how quick company make the payment for PIB. Based on the regulation the process takes only 7 days. However it depend on government bureaucracy and waiting list therefore the delivery process takes longer than expected. Furthermore it could be concluded that the bureaucracy process and working process in SAG are already well structured. The second strongest influenced is Permit with a coefficient correlation value of $0.45\left(R^{2}=20.25 \%\right)$ and strength association "weak". Permit for temporary import is issued by Indonesian trade ministry could not be predicted even though based on regulation this permit needs 14 days to be issued by Indonesian trade ministry this is called (red carpet phenomenon) it is long bureaucracy process.

The third strongest influenced is Incoterms with a coefficient correlation value of $0.42\left(R^{2}=17.46 \%\right)$ and strength association "weak". Based on the analysis the permit is weak to logistics to delivery performance is because on the permit process there were almost on time to the target on permit submission and issuance to the ministry of trade or to customs.
The third strongest influenced is Incoterms with a coefficient correlation value of $0.42\left(R^{2}=17.46 \%\right)$ and strength association "weak". The incoterms is about the obligation between buyer and seller including the carriage of goods, who the one who responsible for the carriage of goods which mode of transportation will be used, where is the port of destination. There are two incoterms that used in $\mathrm{XYZ}$ power plant project 2013 which are FOB and FCA.

FOB The Seller delivers the goods on board the ship and clears the goods for export. From that point, the Buyer bears all costs and risks of loss or damage, whereas FCA the Seller transports the goods, cleared for export, to the carrier chosen by the Buyer. The Seller loads the goods if the carrier pickup is at the Seller's premises. From that point, the Buyer is responsible for the costs and risks of moving the goods to destination. From the two incoterms that used in XYZ power plant project 2013. So the incoterms factor has "weak" influence to logistics delivery performance. The Number of Items factor has a negative coefficient correlation value of $r=$ $-0.36\left(R^{2}=12.96 \%\right)$ and strength association "very weak" and the Documents factor is not influence Logistics Delivery Performance. It has coefficient correlation value of $-0.08\left(R^{2}=0.64 \%\right)$ and strength association "none". The more items was sent, it will not increase the speed delivery. Thus how much items in every shipment not influence to logistics delivery performance.

The Documents factor is not influence Logistics Delivery Performance. It has coefficient correlation value of $-0.08\left(R^{2}=0.64 \%\right)$ and strength association "none". Documents are delivered by the supplier to company were always on time. Thus it has no correlation to logistics delivery performance. However after thorough observation, it seems that PTSI has a problem in internal documentation process and this will affect the whole documentation process. In this research the documents factor was only observed in document preparation from the supplier to the Logistics Energy Service Division. Due to limitation and unavailability of data, in this research does not observed preparation of internal documents process within Logistics Energy Service Division.

In this research, from all those factors, it was found 
that Customs Clearance factor is the strongest factor to influence logistics delivery performance in a power plant 2013 by logistics department in the energy service division since this variable has the strong strength of association with coefficient correlation 0.75 (see Table 3). It was because there were many delay or the target was not achieve in several indicators including PIB Payment, PIB Issuance, Bank Guarantee, and SPPB Customs Release. Therefore, Customs Clearance, Permit, and Incoterms are significant positively influence logistic delivery performance in a power plant 2013 by logistics department in the energy service division.

\section{CONCULISION}

This study is aim to analyze the logistics delivery performance of rental tools delivery for temporary import in XYZ Power Plant Project at the Energy Service Division. The researcher used two aspects to analyze the logistics delivery performance which are from the KPI through delivery reliability measurement of logistics delivery performance levels of rental tools in XYZ power plant project in 2013 and identify influential factors to logistics delivery performance in XYZ power plant project in 2013 by the logistics department in the energy service fossil division. This study used time series data based on XYZ power plant project in 2013 length from September 2013 to December 2013.

To conclude, there are several results that have been obtained based on the findings. This study points out several conclusions: (1) After analysed the delivery process flow, according to the in depth interview, the company has Standard Operating Procedure. However the SOP is not detail, because the process is not precise step by step and there is no detail explanation about each step. Therefore the researcher made an improvement to propose the new SOP. Since SOP is a vital part of any businesses as a guideline of delivery. (2) According to hypothesis \#1 result, the company has an opportunity to improve their KPI Grade, since the KPI grade still insufficient which is $56.67 \%$ in project 2013's delivery reliability. (3) We can conclude that there are positive relationships between Permit, Customer Clearance, and Incoterms factors in influencing logistic delivery performance in a power plant 2013 by logistics department in the energy service division. Permit is the second strongest influenced factor to logistics delivery performance with a coefficient correlation value of $0.45\left(R^{2}=\right.$ 20.25\%) and strength association "weak". Incoterms is the third most influenced factor to logistics delivery performance with a coefficient correlation value of $0.42\left(R^{2}=17.46 \%\right)$ and strength association "weak". Customs clearance has a positive correlation with $r=0.75, R^{2}=56.25 \%$ and strength association "moderate". Thus Customs Clearance is the most influence factor to logistics delivery performance. It has a positive correlation, the highest correlation and strength association "moderate". It means the Customs Clearance is the most factor influence to Logistic Delivery Performance.

\section{Recommendation}

This study provides three types of recommendations: managerial, academic and government recommendations.

\section{Managerial}

Based on the results of this research, there are several recommendations which can be given to a number of related parties as follows:

\section{First Maintain and update Standard Operating Procedure regularly}

The logistics department shall maintain and update regularly the SOP to monitor and make the process in sequence, for example: make annually update review of SOP because there is annual meeting to review whether there are any processes that need to be improved or ineffective process. In addition, the other purpose of detailed SOP is to smoothen the process flow of temporary import (rental tools). With the detailed SOP the logistics staff or even external department who are involved in the project knows the process and also the progress because the other departments do not need ask to logistics officer about detail and progress of the rental tools (temporary import) process.

\section{Second Improve delivery reliability}

Logistic delivery performance measurement is important. Based on the delivery reliability in XYZ power plant project 2013, the company has to improve the logistics delivery performance reliability, this is in line with the finding of Arronson (2004). 
The logistics department should add more lead time for this issue is suggested for the whole delivery timeline In order to increase delivery reliability. For example: According to the standard procedure of the logistics department, the current delivery lead time is 9 weeks for air transportation and 10 weeks for sea transportation, based on the analysis it was still lack of lead time, many rental tools deliveries were late which had a direct impact on achieving total target time of the project. Therefore the company should add 2 more weeks for each type of mode of transportation. For Air transportation is 11 Weeks and for Water transportation is 12 weeks. Thus, the logistics department and the company have much spare time to organize the delivery of rental tools and preventing late delivery.

\section{Third Focus to solve customs clearance issue}

The company should pay much attention to Custom Clearance process, as they could lead to significant Improvement in KPI Grade. For example add more lead time in customs clearance. Customs Clearance affected from four indicators are Bank Guarantee, PIB Issuance, PIB Payment, and SPPB (Custom Release). The company should add more 1 week lead time on permit and 1 week lead time on customs clearance process. Thus add for 2 weeks as total suggested target for both current lead time processes. In order to achieve target and to prevent late delivery that caused penalty from the customer. Based on correlation coefficient of the Customs Clearance model result, in Table 4.7, In table 6 suggested extend of lead time.

Table 6 Proposed Extend lead time on clearance process

\begin{tabular}{cccc}
\hline Description process & Current Target & Suggested Target & Total days \\
\hline PIB Issuance & 7 Days & +4 Days & 11 Days \\
PIB Payment & 5 Days & +5 Days & 10 Days \\
Bank Guarantee & 5 Days & +2 Days & 8 Days \\
SPPB & 6 Days & +3 Days & 9 Days \\
\hline
\end{tabular}

Source: Company data (2013)

Thus, total suggested lead time target is 14 days ( 2 weeks).

\section{Academic}

This study is possible to be extended for further research by several ways as follows: (1) Expanding the period of analysis to collect data of XYZ Power
Plant Project in 2014. With the comparison of the next project, we could know whether there is an improvement or not. (2) Expanding the metrics through delivery dependability, in order to deepen of the analysis in this research. It concerns the ability of the company in terms of delivering the right product, in the right amount and with the right quality. (3) Expanding the measurement of benchmark by conducting external benchmark. For example: Conducting supplier benchmark. By conducting supplier benchmark, we could know the performance of supplier. Since late delivery by the supplier will affect the whole logistics delivery performance. (4) Adding more variable analysis (internal survey) to assess logistics staff performance. For example: Conducting employee satisfaction.

\section{Government}

The government should reduce the lead time of the clearance process. Since the customs clearance is one the significant influence factors to logistics delivery performance. Based on the Directorate General of Customs regulation (Bea Cukai, 2013) the waiting time of clearance process requires 60 working hours which means 7 working days. However due to long bureaucracy process it takes longer than expected. Therefore in order to reduce lead time or waiting time process of customs clearance the government should add more 2 hours from the current working hours which from 8 hours to 10 hours and improving the quality of infrastructure.

\section{REFERENCES}

Aronsson H, Ekdahl B \& Oskarsson B. (2004). Modern Logistik: För Ökad Lönsamhet. Malmö: Liber Ekonomi, 2004.

Baritz, S. G. \& Zissman, L. (1983). Researching Customer Service: The Right Way Proceedings of The National. Council of Physical Distribution Management, vol. II, New Orleans, pp. 608-619, 1983.

Ballou R. H. (1998). Business Logistics Management, 4th ed. Prentice Hall, Englewood Cliffs. NJ, 1998.

Christopher, M. (2005). Logistics and Supply Chain 
Management: Strategies for Reducing Cost and Improving Services. Prentice hall. 3rd edition. 2005

GCi Magazine: http://www.gcimagazine.com/ business/manufacturing supplychain/ 1330 94458.html: Accessed 16 December, 2013.

Hair et al. (2006). Essential of Business Research Methods. London: Wiley, 2006.
Jonsson, P. \& Mattsson, S-A. (2005). Logistik - Läran om effektiva materialflöden. 2005.

Russel S. Robertal, Taylor, W., \& Bernard. (2011). Operation Management. Wiley, 2011.

Stock, G. N., N. P. Greis, \& J. D. Kasarda (1998). Logistics, strategy and structure: a conceptual framework. International Journal of Operations \& Production Management 18: 37-52. 1998. 